\title{
EL JOVEN SIMONET Y EL ESPLENDOR DE LA CIVILIZACIÓN ÁRABE
}

\author{
Young Simonet and the splendor of the Arabic civilization
}

Bernabé LÓPEZ GARCíA

Universidad Autónoma de Madrid ${ }^{1}$

bernabe.lopezg@uam.es

https://orcid.org/0000-0001-6418-6228

Para citar este artículo: Bernabé LÓPEZ GARCÍA (2020): “El joven Simonet y el esplendor de la civilización árabe" em Revista de Estudios Internacionales Mediterráneos, 29, pp. 152-173.

\section{Resumen}

En 1857 el arabista malagueño Francisco Javier Simonet inauguró una cátedra de "Historia Literaria de los árabes en España" con un Discurso sobre la importancia de los estudios árabes claramente laudatorio de las virtudes y logros de la civilización árabe. El contenido de esta lección magistral fue dado a la luz en las páginas de la revista El Occidente y fue reproducido por la revista La América en dos números en diciembre de 1858. El interés que presenta para la historia del arabismo estriba en que nos presenta a un joven Simonet muy influenciado por la idealización de los árabes del romanticismo, que insiste en el contraste del desarrollo alcanzado por dicha civilización en contraste con la decadencia de la cultura en la Europa medieval. Simonet evolucionará años después hacia posiciones diametralmente opuestas para convertirse en el detractor por excelencia entre los arabistas españolas de la civilización musulmana. La REIM reproduce las dos entregas del citado Discurso.

Palabras Clave: Arabismo español/ Simonet/ Al Andalus/ Literatura árabe/ Orientalismo

\section{Abstract}

In 1857, Arabist Francisco Javier Simonet presented a Chair on "Literary History of the Arabs in Spain" with a Discourse on the importance of Arab studies, which clearly praised the virtues and accomplishments of the Arab civilization. The content of the lecture was published on the journal El Occidente (The West) and it was reproduced on the journal La América in two instalments on December 1858. Its interest for the history of Arabism lies on the contribution of a young Simonet

${ }^{1}$ Catedrático honorario de Estudios Árabe e Islámicos, Universidad Autónoma de Madrid. Codirector del Taller de Estudios Internacionales Mediterráneos 
very influenced by the romantic idealization of the Arabs, and who insisted on the contrast between the development reached by this Arab civilization and the decadence of the Middle Age European culture. Simonet would evolved throughout the years towards a completely opposite position, becoming a firm detractor of the Muslim civilization. REIM reproduces the two instalments of this Discourse.

Keywords: Spanish Arabism/ Simonet/ Al Andalus/ Arab literature/ Orientalism

El Discurso sobre la importancia de los estudios árabes ${ }^{2}$ del arabista Francisco Javier Simonet y Bacas (Málaga, 1829-Madrid, 1897) fue pronunciado en el Ateneo de Madrid al inaugurar en esa institución, bajo la presidencia de Francisco Martínez de la Rosa, su cátedra de "Historia Literaria de los árabes en España" en 1857. En los dos cursos posteriores en dicha cátedra se dedicaría a la explicación de lengua y literatura árabes y al estudio del árabe vulgar de Marruecos, puesto de moda con motivo de la guerra de África de 1859-1860.

El Discurso fue publicado por primera vez por entregas en diciembre de 1857 en la revista El Occidente y sería reeditado un año más tarde en la publicación americanista de corte liberal $\underline{L a}$ América. Crónica Hispano-Americana. Inauguraba así el joven discípulo de Serafín Estébanez Calderón una serie de artículos sobre temas árabes que cobraron actualidad con la guerra de África ${ }^{3}$, episodio bélico que tuvo para Simonet un papel de revulsivo, que acabó por instalarlo en una actitud en las antípodas de los ideales liberales y antitradicionalistas que marcaron a aquella revista. Según Leoncio López-Ocón ${ }^{4}$, La América fue una revista universalista, humanitaria, librepensadora e internacionalista. Ello no impidió que la revista apoyara con firmeza, como fue tónica general de la época, la intervención en Marruecos de Leopoldo O'Donnell, con artículos de figuras de muy amplio espectro político como Emilio Castelar, Manuel Ortiz de Pinedo o Antonio Cánovas del Castillo.

El Discurso comienza definiendo el contenido de la materia a impartir en el Ateneo con una alabanza de la civilización árabe:

“Es mi propósito, señores, trazar aunque en breve número de lecciones, el cuadro histórico literario del saber y la civilización, con que un pueblo grande por su poder, por sus armas, por sus artes y por sus letras, ilustró nuestra España en la corriente de los siglos medios. Voy a hablar, señores, de los árabes, pueblo para nosotros de ilustre memoria sobre todos los que han venido a establecerse en nuestro hermoso suelo, porque si bien invasores como los romanos y godos, a ellos solos les debemos la gloria de haber erigido a España en centro de una brillantísima ilustración, mientras espesas tinieblas de ignorancia envolvían el resto de Europa".

La insistencia en que la civilización árabe contrastaba con la decadencia cultural de Europa será uno de los temas insistentes para Simonet, que no ahorró en su Discurso calificativos laudatorios para el propio carácter de los árabes:

"Los árabes, señores, pueblo ilustre desde la antigüedad más remota por su generosidad hospitalaria, su largueza, su valor, su carácter noble e independiente, su espíritu

\footnotetext{
${ }^{2}$ El Occidente, 20, 22, 24, 27, 29 de diciembre de 1857.

${ }^{3}$ LÓPEZ GARCÍA (1971): "F. J. Simonet ante el colonialismo (1859-1863): unos artículos en La América", Cuadernos de Historia del Islam, 1 serie miscelánea (1971), pp. 159-178. Reproducido en LÓPEZ GARCíA (1997): Marruecos y España. Una historia contra toda lógica, Sevilla: RD Editores-Historia.

${ }^{4}$ LÓPEZ-OCÓN CABRERA, L. (1982): "La América. Crónica Hispano-americana: Génesis y significación de una empresa americanista del liberalismo democrático español", Quinto centenario, 4 pp. 137-174. El Discurso de Simonet fue reeditado en los números 19 y 20 del 8 y 24 de diciembre de 1858.
}

REIM № 29 (diciembre 2020) ISSN: $1887-4460$ 
conservador en las cosas propias y tolerante en las ajenas, realzaron tan altas cualidades con las dotes más encumbradas de la inteligencia y el ingenio".

Una de las intenciones de Simonet en el curso impartido en el Ateneo madrileño será la defensa de la necesidad de protección de los estudios árabes en España, cuya utilidad para la reconstrucción del pasado histórico hispano defiende:

"De todo esto se colige la necesidad de los estudios árabes para ilustrar y aun rehacer una parte muy considerable de nuestra historia. Aun en la parte que atañe únicamente a nuestros muslimes, es importantísima su historia, pues nos presenta glorias y altos hechos que recaen en loor de nuestra España, cuyos moradores fueron durante tantos siglos, capitanes y guerreros famosos, sabios y poetas ilustres, monarcas y conquistadores que dilataron sus señoríos por España y África, otros espléndidos y magníficos en adornar nuestro suelo con ricos monumentos de las artes y en proteger las letras, y todos ellos respetados y obsequiados con presentes y homenajes de soberanos y príncipes de Oriente y Occidente: tales son los lauros y blasones de los árabes que dominaron en nuestra Península".

Estas ideas las desarrollará más tarde en la Universidad de Granada con motivo de su recepción como catedrático, el 15 de septiembre de $1862^{5}$, en su discurso dedicado a "demostrar la utilidad del estudio y cultivo de la lengua arábiga para ilustrar la historia de nuestra nación con los documentos en ella escritos".

En el discurso de La América insistirá en contraponer las luces de la Andalucía árabe frente a la ignorancia medieval europea:

"Solamente debemos encarecer, como punto que interesa en extremo a nuestra gloria nacional, cuánto nos importa estudiar la lengua y literatura de ese pueblo, que en medio de la rudeza y de la ignorancia de la edad media, brillaba en nuestro suelo con el lustre de sus madrisas o academias llenas de sabios en todas las ciencias y con todo el esplendor y magnificencia de sus artes, con que tan soberbios monumentos erigían en Córdoba, Sevilla y Granada".

No debe escaparse la significación nacionalista que Simonet da a este esplendor hispano-árabe, con esa insistencia en que se produce en "nuestro suelo", "nuestro hermoso suelo", "nuestra España". Y será ese zócalo hispano, con raíces históricas más profundas, el que a lo largo de su producción literaria y arabista exaltará, para acabar personificándolo en la minoría mozárabe que convertirá en la guardiana de las esencias de la españolidad. A esta minoría dedicará su obra magna Historia de los mozárabes de España: deducida de los mejores y más auténticos testimonios de los escritores cristianos y árabes ${ }^{6}$.

He afirmado más arriba que la guerra de Tetuán actuó de revulsivo en Simonet contribuyendo a relativizar su defensa a ultranza de la civilización árabe que mostraba en el Discurso del Ateneo. La investigadora mexicana Isis Monserrat Guerrero Moreno plantea en un artículo que "el arabista siempre mantuvo cierto escepticismo respecto de las cualidades arábigas y musulmanas" ${ }^{7}$. Sin duda el hecho de haber sido discípulo de Serafín Estébanez Calderón debió influir en una visión

\footnotetext{
${ }^{5}$ Francisco Javier Simonet, Discursos leídos ante el Claustro de la Universidad Literaria de Granada en el acto solemne de la recepción del licenciado Francisco Javier Simonet como catedrático numerario de la lengua árabe en la Facultad de Filosofía y Letras el día 15 de septiembre de 1862, Imp. Zamora, Granada 1866.

${ }^{6}$ Publicada por la RAH, Madrid 1897-1903.

${ }^{7}$ GUERRERO MORENO, Isis Monserrat (2019): “Entre maurofobia y maurofilia: formación e impacto del pensamiento historiográfico de Francisco Javier Simonet", Revista de Estudios Internacionales Mediterráneos, no 27, pp. 203-223. https://doi.org/10.15366/reim2019.27.013
} 
negativa de la situación real del mundo islámico en su tiempo. Estébanez, en su Manual del oficial en Marruecos calificaba la sociedad de este país de

"sociedad semi-bárbara [que] no ofrece aliciente para las consideraciones del filósofo, ni la monótona y pavorosa relación de los puñales y tósigos de su historia, hacen sabrosas las investigaciones del historiador"

y apuntaba que un conocimiento del país, razón por la que escribió la obra, resultaba útil para un momento, 1844, en el que se hablaba de "preparativos militares" para una intervención en Marruecos que no llegó a producirse.

Simonet en su Discurso es consciente de que el prestigio de la civilización árabe, en la cultura y en la política, forman parte del pasado, pero su decadencia en el momento en que escribe su texto no debe impedir el reconocimiento de su gloria:

"Es cierto que este predominio político y literario de los árabes que hemos venido mostrando, terminó hace algunos siglos, y que la civilización muslímica ha sido borrada juntamente con su dominación de estas regiones que tenían usurpadas; pero por las muchas y gloriosas huellas que de ellos han quedado, así en España como en otros países de Oriente y Occidente, se ve que no han sido perdidos aquellos elementos para nuestra civilización moderna. Su actual decadencia nada puede quitar de este lustre y gloria".

En la conclusión de su Discurso es donde aparece el embrión del Simonet integrista o arabizante ultramontano como lo califica su biógrafo, Antonio Almagro Cárdenas ${ }^{9}$, ideología que irá desarrollándose a lo largo de su vida:

“Entusiasta admirador, durante su juventud, de la cultura arábiga, modificó luego estas ideas, poniendo verdadero empeño en demostrar que la literatura y las artes de los árabes nada tienen de original, y que hasta su idioma tomó mucho de las naciones en donde la religión de Mahoma posó su planta" ${ }^{10}$.

Ese providencialismo histórico como lo califiqué en un viejo trabajo ${ }^{11}$, característico de la visión historiográfica de Simonet, estaba ya patente en la conclusión de su Discurso, convencido de la misión providencial reservada a España en el norte de África, a manera de revancha histórica frente al islam:

"Réstame, señores, manifestar que el fomentar los estudios árabes, es necesario para nosotros, los españoles, si animados de antiguos sentimientos religiosos y nacionales, queremos dar impulso á las misiones de Oriente y restablecer las de África, reivindicando los antiguos derechos que nos asisten para tener templos y casas de misión en el imperio de Marruecos; y más todavía, si con altas y grandes miras pensamos en dilatar algún día por esas comarcas, teatro de nuestras antiguas glorias, la religión del Crucificado y la dominación española".

\footnotetext{
${ }^{8}$ ESTÉBANEZ CALDERÓN, Serafín (1844): Manual del Oficial en Marruecos. Cuadro geográfico, estadístico, histórico, político y militar de aquel Imperio. Madrid: Imprenta de Ignacio Boix.

${ }^{9}$ ALMAGRO y CÁRDENAS, Antonio (1904): Biografía del Dr. D. Francisco J. Simonet catedrático que fue de lengua árabe de la Universidad de Granada, Granada. Disponible en https://archive.org/details/biografiadeldoc00crgoog [Acceso: 4 de diciembre de 2020].

${ }^{10}$ Ibid., p. 75.

${ }^{11}$ LÓPEZ GARCÍA, Bernabé (1974): “Expansión colonial e ideología religiosa. Un caso típico: el africanismo y arabismo de la segunda mitad del siglo XIX español", Actas del Primer Congreso Islamo-cristiano. Córdoba.
}

REIM № 29 (diciembre 2020) ISSN: $1887-4460$ 
DISCURSOS sobre la importancia de los estudios árabes, pronunciados en el Ateneo científico y literario de Madrid (I)

\author{
La América, 8 de diciembre de 1858 \\ POR DON FRANCISCO JAVIER SIMONET
}

Es mi propósito, señores, trazar aunque en breve número de lecciones, el cuadro histórico literario del saber y la civilización, con que un pueblo grande por su poder, por sus armas, por sus artes y por sus letras, ilustró nuestra España en la corriente de los siglos medios. Voy a hablar, señores, de los árabes, pueblo para nosotros de ilustre memoria sobre todos los que han venido a establecerse en nuestro hermoso suelo, porque si bien invasores como los romanos y godos, a ellos solos les debemos la gloria de haber erigido a España en centro de una brillantísima ilustración, mientras espesas tinieblas de ignorancia envolvían el resto de Europa. Grande empresa para mis escasas fuerzas es la que me he propuesto, mas espero que la importancia del asunto suplirá mi falla de ingenio y de elocuencia. También aspiro á merecer mas particular indulgencia a mis oyentes, porque voy a consagrarles trabajos debidos únicamente a la fe y al amor de las cosas patrias, puesto que para ellos apenas nos han abierto camino nuestros mayores, ni por desgracia merecen fomento, aplicación e interés a nuestros contemporáneos. Pero el desdeñar los estudios árabes podrá tener explicación, ya que no excusa, en aquellos tiempos en que aun se mantenía vivo el odio contra la dominación de aquellos conquistadores, cuando se les perseguía por infieles, cuando en cada volumen árabe se miraba un alcoran, y en odio de los musulmanes y moriscos no había reparo en entregar al fuego por un excesivo celo religioso los documentos de nuestra historia nacional. Y a este propósito, señores, trazaré en breves palabras el relato de las vicisitudes que ha corrido en nuestra España el estudio de la lengua y de la literatura árabe.

Desde el siglo VIII al XV, el ascendiente del imperio y la civilización muslímica, y la necesidad de mutuas relaciones entre los dos pueblos que habitaban en la península española, fueron parte para que muchos de nuestros cristianos estudiasen la lengua y las letras arábigas y aun adoptasen su escritura, como veremos después, descuidando el estudio de su lengua patria y de la latina su natural madre. Un autor de aquella época (citado por Ducange en su glosario de la media e ínfima latinidad), dice que aquellos cristianos cultivaban con tal esmero la erudición e idioma de los sarracenos, con abandono de la lengua propia y latina, que mientras innumerables de ellos salían aventajados en explicar las locuciones y bellezas del árabe, apenas había uno por cada mil que supiese dirigir a otro cristiano una carta de cumplimiento y saludo. Entonces los cristianos españoles hacían gala de saber árabe, y así es que en documentos escritos en lengua latina o vulgar, solían poner sus rúbricas y nombres en caracteres árabes, tal vez por darles así más importancia y autoridad. Hasta los tiempos más adelantados de nuestra restauración se encuentran documentos escritos en árabe por los cristianos de Andalucía, unos que versan sobre nuestras relaciones con los moros y otros exclusivamente sobre cosas españolas. La multitud de moros mudéjares, y sobre todo de mozárabes, que solían quedar en las ciudades nuevamente restauradas, daba ocasión también a que se cultivase por los cristianos el estudio del árabe, porque sabido es que los mozárabes, aunque conservaban en su lengua algo del latín, hablaban por su mayor parle el idioma de sus señores.

En nuestra historia del siglo XI se lee un hecho que puede ilustrar en algo este asunto. Cuéntase que cuando la memorable derrota de los moros en la jornada de Calatañazor un pescador de Córdoba recitaba en las orillas del Guadalquivir unas estrofas, ya en árabe y ya en latín, alusivas a aquel suceso, que terminaban así:

"En Calatañazor perdió su atabal Almanzor". 
Aquel pescador, que recitaba en árabe y latín, es muy verosímil que fuese uno de los mozárabes de Córdoba, que se alegraba por la derrota del gran enemigo de su religión. Las frecuentes ocasiones con que los cristianos se pasaban a tierra de moros, ya como refugiados y fugitivos de Castilla, ya como aliados y auxiliares de los mismos infieles, les obligaban al estudio de la lengua árabe. Por aquel tiempo acudían á la España sarracena desde apartados confines, no solo del mundo musulmán sino hasta del cristiano, muchos varones amigos del saber a buscar la ciencia en las famosas academias de Córdoba y Sevilla. Entre otros es célebre el nombre de Gerberto $\left({ }^{12}\right)$, monge francés que, pasando a Sevilla, estudió por espacio de tres años con los doctores moros de esta ciudad las matemáticas, retórica, astrología y otras ciencias y aun se dice que la magia. Gracias á los conocimientos aquí adquiridos, cuando volvió a su país asombró a sus compatriotas con su sabiduría y se abrió camino sucesivamente a las altas dignidades de arzobispo de Rheims, y después de Rávena, y por último ocupó la silla pontificia con el nombre de Silvestre II. Sabido es también que el rey $\mathrm{D}$. Alonso el Sabio estableció en Sevilla escuelas de árabe y cuantos estudios y traducciones merecieron a él y sus contemporáneos los libros arábigos.

Cuando nuestros antepasados sacudieron del todo el yugo sarraceno; pero quedaron en España muchos súbditos moros e innumerables vestigios y monumentos de aquella dominación, siguiéronse cultivando tales estudios y entonces vio la luz, impresa en Granada, la importantísima gramática árabe del P. Alcalá, la primera que de esta lengua hubo en los idiomas vulgares de Europa, y que todavía se considera y estudia por los orientalistas extranjeros como un precioso monumento de la lengua de los árabes españoles. Pero ya las continuas y aun sangrientas reyertas con los nunca bien dominados moriscos, y el espíritu de borrar de nuestro país todo resto de la religión mahometana, hicieron que se mirase con odio todos los monumentos árabes, y en particular sus libros se condenaron miserablemente al fuego por el tribunal de la inquisición. Así es que en este tiempo apenas se cultivaba ya el árabe sino es por algunos moriscos, como lo fueron Alonso del Castillo $\left({ }^{13}\right)$ y Miguel de Luna, a quienes nuestros reyes lo permitieron así para tener intérpretes de quienes valerse en sus relaciones con los Xarifes y otros soberanos de África y Oriente. Así decayeron en España estos estudios, hasta que en el siglo pasado nuestros ínclitos monarcas Fernando VI y Carlos III, amantes y favorecedores de todo lo útil, deseosos de dar impulsos á nuestra historia, sacaron a la literatura arábigo-hispana del abandono y olvido en que yacía. Fernando VI hizo venir desde la Siria a Casiri y otros maronitas para que trabajasen en el aprovechamiento de los numerosos manuscritos árabes que atesora la biblioteca del Escorial. Carlos III les continuó dispensando la más liberal protección y además abrió en los estudios reales de San Isidro cátedras de árabe y otras lenguas orientales. Merced á las ilustradas disposiciones, se hicieron por mano de aquellos y otros orientalistas, copias de muchos manuscritos curiosos, y Casiri trabajó el índice de los que encierra dicha Biblioteca, aprovechando y consignando de paso muchas de sus noticias y curiosidades, principalmente históricas. Aunque aquellos orientales, faltos por su mayor parte de los conocimientos auxiliares necesarios para sacar mayor partido de los libros árabes, no lograron este objeto tan cumplidamente como fuera de desear, hicieron trabajos muy útiles, y lo que es más, plantaron en España una escuela y semillero de orientalistas. A este impulso y protección dispensada por aquellos grandes reyes, se debió la aparición del $P$. Patricio de la Torre, de Banqueri, de Lozano y Caseto, de Aso y del Rio, de D. Faustino de Borbón, de Conde, de Bacas y Merino y tantos otros orientalistas, que tan excelentes traducciones, copias y otros trabajos dejaron hechos en el ramo de la historia, en el de la geografía, en el de la amena literatura, en el de la agricultura, historia natural y otras ciencias, los cuales con gran lujo y

\footnotetext{
${ }^{12}$ Fue natural de la Auvenia y murió en 1003 de nuestra era.

${ }^{13}$ Este nos ha dejado un precioso libro manuscrito donde se contienen las copias y traducciones de las inscripciones árabes de la Alhambra y Generalife, que posee nuestro respetable amigo el Excmo. Sr. D. Serafín E. Calderón.
}

REIM № 29 (diciembre 2020) ISSN: $1887-4460$ 
perfección tipográfica salieron a luz honrando la imprenta española. Entre otros frutos no menos sazonados de aquel abono, se debió el entusiasmo con que el ilustre español $D$. Domingo Badia Leblich, célebre en el mundo sabio con el nombre do Ali Bey, y más famoso aun entre los extranjeros que entre sus naturales, pasó al África y al Oriente, se hizo tener por un emir árabe, visitó la mezquita de la Meca y sepulcro de Mahoma, hizo importantes trabajos históricos y descriptivos de los países orientales y llamó hacia estas regiones la atención de la Europa sabia.

Pero en tan buen punto sobrevino, señores, una tempestad que descuajó las plantas y semillas de las letras árabes no arraigadas todavía suficientemente en nuestro suelo. Primero, la guerra desastrosa de la independencia, y después las convulsiones políticas-que han agitado la España en este siglo, han sido la causa de que se pierda el fruto de aquel cultivo: por falta de protección y de aliciente que llamasen nuevos adeptos. Así fue, que si bien no falló después de la muerte de los ya nombrados algún arabista distinguido como el P. Artigas, que prosiguiera en esta enseñanza, sin embargo, careciendo de libros con que ensanchar sus conocimientos, tuvo que reducirse a explicar les sencillos y concisos preceptos gramaticales de Erpenio. Es cierto que españoles eminentes han hecho de algunos años á esta parte grandes esfuerzos para aclimatar nuevamente entre nosotros este importantísimo estudio, particularmente D. Serafín Estébanez Calderón, mi dignísimo maestro en esta lengua, y que con sabias y elocuentes explicaciones la ha recomendado en estas mismas cátedras. Aquí también se han oído con placer las lecciones de otros distinguidos arabistas, entre los que me bastará nombrar al ilustrado catedrático de esta lengua en la Universidad de Madrid, don Pascual de Gayangos, al Sr. Moreno Nieto, que desempeña la de Granada, y a mi apreciable compañero el Sr. Malo de Molina, que en estas aulas explica las reglas del idioma arábigo $\left({ }^{14}\right)$. Pero es no menos cierto que los conatos individuales de estos y otros sabios varones, son insuficientes para que los estudios orientales vuelvan a florecer, como lo necesita nuestra historia y como cumple a nuestra gloria nacional, sin el eficaz apoyo de los hombres del gobierno. Hoy, señores, son los extranjeros los que cultivan las letras árabes; en Francia, Inglaterra, Holanda y Alemania, naciones que casi ningún recuerdo conservan de aquellas gentes, hay abiertas numerosas cátedras de árabe, y salen a luz, ya los textos originales, ya traducciones y otros importantes trabajos sobre aquellos autores. Entre los orientalistas que honran aquellos países, son dignos de especial memoria los nombres de Causin de Perceval $\left({ }^{15}\right)$, Hammer, Slan, Dozy $\left({ }^{16}\right)$ y otros muchos que con los documentos árabes se dedican á ilustrar nuestra historia. Tampoco debo olvidar y aunque murió hace años, al célebre barón Silvestre de Sacy, honra de la Francia y patriarca de las letras árabes en la moderna Europa, en cuyo elogio bastará decir que escribió en aquella lengua un comentario a las célebres Macamas del Hariri $\left({ }^{17}\right)$, con tal perfección en el lenguaje y estilo, que leyéndole algunos ulemas y alfaquíes, creyeron que era en realidad obra de un sabio árabe. Entretanto nosotros, con sentimiento y vergüenza lo confieso, después de haber aventajado en estos estudios a toda Europa, hoy, mirando con lastimosa apatía nuestra historia y nuestros recuerdos, dejamos a los extranjeros el cuidado de hacer aquello a que mas estamos obligados. Aquellas naciones, señores, han vuelto los ojos a la literatura árabe y oriental, ya por cumplir los deberes que impone la civilización, ya por las campañas y empresas de armas que algunas de ellas han llevado a cabo por África y Oriente, ya por el deseo de conocer aquellas regiones, cuna del sol, de la poesía y de todos los conocimientos humanos. Pero este interés por parte de los extranjeros,

\footnotetext{
${ }^{14}$ Tampoco debo pasar en silencio al distinguido filólogo D. Enrique Alix, a quien una muerte harto temprana ha arrebatado con gran detrimento de los estudios árabes, dejando empezada y muy adelantada tal vez una versión castellana del célebre poema de Antara.

${ }^{15}$ Autor de un excelente ensayo sobre la historia de los árabes antes del islamismo y hasta la conversión de todas sus tribus á esta religión. París: 3 tomos $4^{\circ}$.

${ }^{16}$ Autor de una apreciable obra, titulada, Recherches sur l'histoire politique et Litteraire de l'Espagne pendant la moyen age. Leiden, 1819.

${ }^{17}$ Este comentario es el que acompaña a la gran edición del Hariri, hecha en Paris por el mismo Sacy en folio.
} 
y aquel desdén por la de nuestros españoles, me obligan a examinar en esta primera lección, si en efecto la lengua y literatura de los árabes, ya considerada absolutamente, ya en sus relaciones con los demás pueblos del mundo, y sobre todo con los españoles, merecen el gran valer y estima que la Europa sabia le atribuye.

Los árabes, señores, pueblo ilustre desde la antigüedad más remota por su generosidad hospitalaria, su largueza, su valor, su carácter noble e independiente, su espíritu conservador en las cosas propias y tolerante en las ajenas, realzaron tan altas cualidades con las dotes mas encumbradas de la inteligencia y el ingenio. Desde remota antigüedad alcanzaron algunos conocimientos en astronomía, agricultura, tradiciones, genealogías, ciencias morales, y especialmente en la historia, a causa de sus navegaciones y relaciones de comercio con los países vecinos. Pero en donde más descollaron, fue en la poesía, incitados a su cultivo por su ardiente imaginación, el espectáculo de la naturaleza y las emociones de su vida pastoril, nómada y aventurera. En este punto ningún otro pueblo le lleva ventaja, pues en tiempo que no formaba nación sino solo tribus y hordas errantes, contaban entre ellos una inmensa ilustración poética, cuyos numerosos monumentos aun se conservan y son la fuente de su poesía clásica. Mucho interesa el ver a aquellos árabes nómadas, así amigos como enemigos, reunirse todos los años en la célebre plaza de Ocald, para celebrar certámenes literarios y competencias de ingenio, deponiendo, antes de entrar en la arena del palenque, sus armas, y con ellas los rencores y hostilidades que siempre los dividían, y haciendo recitar sus poemas por un rawi o narrador enmascarado, para que las glorias militares que celebraban los unos no ofendiesen a los otros, a quienes aquellos lauros hubiesen costado su afrenta o la sangre de sus parientes y amigos. Pero todavía se formará más alto concepto del amor de aquellas gentes a la poesía, cuando se recuende que las tribus árabes celebraban la aparición de un buen poeta como uno de sus más grandes sucesos, y que entre otros premios con que liberalmente los recompensaban, era el más principal el exponer sus obras a la pública admiración en el famoso templo de la Meca, conocido con el nombre de la Caba, especie de santuario consagrado por ellos a la deidad de la poesía. Y todavía, señores, los modernos árabes del desierto que conservan sin alteración los antiguos y tradicionales usos de sus mayores, aunque decaídos de su antigua grandeza literaria, ofrecen a los ojos del mundo civilizado un ejemplo continuo y notable de su innata afición a la poesía y la veneración que profesan a las obras maestras de su literatura. Hoy, señores, desde el África occidental hasta la Siria y Arabia, se juntan las cabilas y poblaciones árabes, ya en medio de sus aduares, ya en el campo y a la luz de la luna, para escuchar de la boca de sus recitadores, llamados jabires y rawies, las poesías y leyendas de los antiguos vates del desierto. Entre estos narradores, los que atraen más concurrencia, son los llamados Antaries, por recitar los versos y poéticos relatos de la Sira de Antara, célebre epopeya de la nación árabe y encomio de uno de sus más afamados héroes que aquellas gentes escuchan siempre con extraordinarias demostraciones de admiración e interés.

Cifrado en la poesía el gusto literario de los antiguos árabes, sobresalieron poco en los demás ramos del humano saber, y nada alcanzaron de las doctrinas filosóficas, porque, según confiesan sus mismos autores, a pocos de ellos les concedió Allah ingenio a propósito para tales estudios. Pero luego que Mahoma y los primeros califas, formando de los árabes una gran nación, los empeñaron en la conquista del mundo, estas gentes, con una sed insaciable de saber, en todas partes buscaron elementos para instruirse y civilizarse. Es cierto que Mahoma se mostró enemigo de los poetas, hizo borrar los poemas que se veneraban en la Caba, y pareció condenar las letras profanas, pero, como dice un historiador árabe, esta prohibición solo era temporal, no queriendo que los hombres se distrajeran de la religión y de las armas hasta asegurar su fe y asentar firmemente los fundamentos del Islamismo. 
El advenimiento de esta religión, aunque grosera y sensual, fue al cabo utilísimo a la civilización y literatura de los árabes, pues siendo estos por su mayor parte idólatras, el Corán les enseñó el dogma de la unidad de Dios y la abolición de las supersticiones gentílicas, la inmortalidad del alma, y las penas y premios en la otra vida; de suerte, que esto les obligó á reformar las costumbres y les inclinó a estudios más espirituales y filosóficos. Así promulgado el Corán, y caminando los árabes a su grandeza, dieron nuevo y más útil impulso a su literatura. Son muy celebrados por los historiadores árabes los califas Abbasitas, Almanzor y Almamun, que despachando embajadas a los emperadores griegos, obtuvieron de ellos ejemplares de sus mejores obras de filosofía, medicina y otras ciencias, haciéndolas después traducir al árabe y protegiendo sobremanera su estudio. En sus expediciones a la Persia, la India, el Egipto y la Siria, con mayor ansiedad de ciencia que de conquista y botín, recogieron todos los elementos y semillas de saber que creyeron útiles. Así llegaron á familiarizarse con Platón, Aristóteles, Ptolomeo, Hipócrates, Euclides, Galeno, Zoroastro, Hermes, Bidpai, los brahmas y los magos, enriqueciendo juntamente su idioma con multitud de palabras científicas que hallaron en aquellos autores extranjeros. Entretanto, no abandonaban el cultivo de la poesía, su más natural y favorito, pues así en Oriente como después en España, volvieron a contar los árabes gran número de ilustres ingenios que en las dotes poéticas, si no superaron, no reconocieron ventaja a los anteriores a Mahoma. La generosidad de los califas y emires se distinguió en favorecer a los adeptos de la poesía con grandes honores y magníficos presentes. Entre aquellos ilustrados monarcas merecen señalada memoria el califa Harun Arraxid, tan conocido por los cuentos de las Mil y una Noches, que dispensando a las letras desde su corte de Bagdad la más eficaz protección, logró que floreciesen sobremanera, siendo la historia de su reinado una de las páginas más brillantes y gloriosas que encierran los fastos de la literatura en el mundo. Esta civilización de los árabes, yendo en aumento con su poder y sus conquistas, les permitió ilustrar gran parte del mundo con sus academias, con sus sabios, con libros de todas las ciencias y doctrinas, y con los monumentos de sus artes, devolviendo con usura a otros pueblos el saber que habían tomado de ellos y dando nueva civilización a indios, persas, turcos, africanos y españoles. Para tributar el debido elogio a la inmensa ilustración árabe, no es necesario ni posible el celebrar aquí a los grandes ingenios que ha producido en largas edades y apartadas comarcas del mundo. Baste recordar que entre sus poetas son famosos Antara, Amrulcais, Almotanabbi, Abulalá, y Ebn Zeidun de Córdoba; entre sus médicos Ebn Sina ó Avicena; entre sus naturalistas el Cazwini, entre los filósofos Alquendi, Averroes y el Gazzali; entre los astrónomos Albatheni ; entre los Oradores y prosistas Hariri y Ebn Nobatha; entre los geógrafos Xerif el Idrisi, mal llamado Nubiense, y el viajero Ebn Bathutha, y entre los historiadores Ebn Jaldun, Abulfeda, nuestros españoles Ebn Hayan y Ebn Aljathib y tantos otros que sería prolijo enumerar. En el género de la epopeya, el que más sublima a una nación, por ser como la apoteosis de sus glorias nacionales y literarias, cuentan los árabes entre otras una tan señalada, el poema de Antara, que con mucha ventaja puede comparársele con la llíada de Homero, El Xah Nameh de Firdusi y la Eneida de Virgilio, superándolas lal vez en la descripción de las antiguas costumbres y espíritu de los árabes, naturalidad e interés de su relación. El que desee conocer a fondo el rico tesoro literario de los árabes de aquella época, consulte las célebres colecciones llamadas Quitab alaghani alquebir o gran libro de las canciones, la Hamasa, colección de poesías heroicas de los árabes del desierto, las siete Moallacas y sus comentarios, las obras literarias del egipcio Osyuthi de Ebn Jallican, etc., y hallará en ellos tal copia de monumentos históricos y literarios desde los antiguos árabes hasta los tiempos de su dominación en España y África, que no podrá menos de admirar tan varia y rica literatura. Para conocer á sus autores más modernos, consúltese siquiera el diccionario bibliográfico de Hachi Jalfa, en donde se halla noticia de cuarenta mil obras y ocho mil escritores árabes $\left({ }^{18}\right)$.

\footnotetext{
${ }^{18}$ La mayor parte de los libros árabes que dejamos citados, han visto la luz pública en su texto original en Paris,
} 
Así, pues, aunque las letras árabes no hubiesen ejercido en las demás naciones la grande influencia que demostraremos después, bastaría la multitud de sus conocimientos, su variedad, amenidad y curiosidad para la historia de las letras, para interesar a los hombres amantes del saber en su estudio y cultivo. ¡Cuán bella, rica y poética es su lengua! Su riqueza es tal que sus diccionarios abrazan muchos tomos; para expresar cualquier cosa o idea tiene gran copia de palabras y frases: por ejemplo el adverbio afirmativo bien puede enunciarse de muchas maneras: taib, hasanan, naaman, chamilan, bijeir, melih, etc. Los autores árabes dicen que el león tiene dos mil nombres, la espada quinientos, los ojos doscientos, y nosotros, al menos hemos tenido la paciencia de contar en los diccionarios actuales más de cien nombres del león.

La lengua árabe (dice un sabio orientalista) $\left({ }^{19}\right)$ es la más rica de las lenguas orientales, pues a veces tiene mil sinónimos para una palabra, y no es menos notable por su armonía, su concisión para expresar las ideas, su fuerza y majestad; es la más antigua y bien conservada de las vivas, pues se habla hoy en los desiertos del Arabia como hace cinco mil años, y es la más vasta y extendida por el mundo. Y merced al conocimiento de esta lengua, icuántas bellezas no se saborean en la lectura de sus libros! Entre ellos todo toma un gusto y ornato poético: los hombres, y en particular el bello sexo, usan nombres alegóricos expresivos de la hermosura u otras cualidades, como Maassamá, agua del cielo, Sobh mañana, Bedr Bodur, luna de las lunas, Zahra flor, Ayyal gacela, Wardnisan rosa de marzo. Las flores y aves se conocen con otros nombres que añaden belleza y poesía a la que ya tienen en sí, como sultana de los montes a la madre selva, Ommalhasn o madre del encanto, al ruiseñor, dzicrallahi o loor de Dios a la tórtola, jaddaladzar o mejilla de una virgen a la anemona. Hasta las ciudades reciben de ellos nombres poéticos, como Sarmanraá "alégrase el que la vé», Alaraich o Larache el pabellón, Azahira la florida, Almería el espejo, Medina Annaim la ciudad de las delicias o sea Bagdad, etc. Su poesía, siempre descriptiva, abunda en las imágenes más risueñas de la naturaleza.

Las imágenes de la aurora, la palma, la gacela, las ramas flexibles del ban y otras con que describen los encantos de las mujeres, son siempre hermosas como tomadas del cuadro inagotable y siempre nuevo de la naturaleza. Sus descripciones del león, del caballo, de los prados, las nubes y los arroyos son bellísimas y risueñas, trasladando al lector con el pensamiento a los risueños e inmarcesibles vergeles del Edén.

Concluiremos este elogio y retrato literario de los árabes, afirmando que si de otros pueblos tomaron los gérmenes de muchas artes y ciencias, ellos las perfeccionaron e imprimieron en ellas un carácter particular, y que en cuanto al ingenio, numen y arte poético, no son discípulos de nadie, sino que nacieron entre ellos mismos con la contemplación de la naturaleza y su imaginación privilegiada.

Pero de estas razones generales conviene que pasemos ya a otras de mayor aplicación e interés más inmediato para nosotros los occidentales. Sí es cierto que la importancia de la literatura de un pueblo debe estar en proporción con el ascendiente e influencia que este mismo pueblo ha tenido en los grandes destinos la humanidad, y por las huellas que ha impreso en la vida y estado de las demás naciones, no puede ponerse en duda la inmensa importancia de las letras y cultura árabe. Así lo testifican los grandes recuerdos y monumentos que ha dejado en el mundo aquella nación

Londres, Leiden, Berlín, Viena, Roma y otros centros de la civilización europea. El sabio alemán J. Hammer Purgstall ha publicado una obra en siete tomos sobre literatura árabe, que por ignorar la lengua alemana, tengo el sentimiento de no haber podido consultar para mis lecciones.

${ }^{19}$ Juan Humbert, en una disertación sobre la utilidad del árabe. 
que durante muchos siglos extendió su imperio por el norte hasta Francia, la Italia y el imperio griego, por el Mediodía hasta el Sahara, el Sudan y la Nubia, y por Oriente hasta las riberas del Ganges y fronteras de la China, y que aun hoy le dilata desde el mar de las Indias hasta las costas occidentales vecinas á nuestras Canarias. Aunque eclipsado ya el sol de su antigua ilustración, y casi reservada esta a los libros gloriosos e innumerables vestigios atestiguan por el mundo su marcha civilizadora. Hoy, señores, el árabe beduino del Hichaz y del Yemen, siempre libre e independiente en medio de sus patrias soledades, como hace tres mil años, mira en derredor de sí dilatados países, subyugados en otro tiempo por sus hermanos, y en parte convertidos en heredamiento de la raza de Ismael, y en parte sembrados de huellas casi indestructibles de un predominio político y literario. Al Occidente, la mayor parte del África septentrional desde Marruecos al Egipto y fuentes del Nilo conservan la raza árabe, su lengua, su religión dominante, sus leyes y costumbres, y mil monumentos de sus artes. Entre Oriente y Norte la Persia, el Indostán y muchas islas de estos mares, conservan rastros de su dominación vencedora en el idioma, en la religión, en los nombres geográficos, en la arquitectura de alcázares y mezquitas, en los diferentes ramos de la literatura, y en todos estos países la escritura es la arábiga. Más al Norte, en la Siria y otras comarcas confinantes, habitadas aun por la raza semítica del Éufrates hasta las costas del Mediterráneo, la lengua, las costumbres, la religión y todos los monumentos artísticos y literarios son árabes; y hoy día, en Jerusalem, la soberbia mezquita del árabe Omar, se alza sobre los cimientos del antiguo templo de Salomón. Igual triunfo de los islamitas, en desdoro y afrenta de los cristianos, se advierte en la antigua basílica de Santa Sofía, hoy consagrada al culto que propagaron los árabes. Pero además de la religión mahometana abrazada por los turcos, este imperio debe a los árabes su civilización, su lenguaje oficial y cortesano, muchas palabras del vulgar y muchos monumentos de arquitectura arábiga, que han eclipsado a la antigua bizantina. Mas, al Occidente, las islas del Mediterráneo conservan muchos vestigios árabes; en las de Malta aun se habla su idioma; la de Sicilia encierra magníficos monumentos, alcázares y palacios fundados por aquellos conquistadores, entre ellos los famosos de la Cuba y la Ziza. En la Provenza. Languedoc y otras comarcas meridionales de Francia, aunque apenas dominadas por los sarracenos, aun quedan algunas memorias de estos conquistadores. Semejantes y mayores recuerdos de los árabes se ven en nuestra península, como lo diremos después con mas extensión; de suerte, que en toda la zona templada del antiguo mundo, en donde el cielo es mas azul y la naturaleza mas risueña, ha sembrado sus monumentos aquel pueblo civilizador para compartir gloriosamente en sus artes con los antiguos egipcios, asirios, griegos y romanos.

Pero si estos vestigios y monumentos nos demuestran la importancia de los estudios árabes para ilustrar la antigua historia artística y literaria de los demás pueblos, todavía hallaremos en sus libros razones más poderosas en favor de tales estudios. Los árabes nos han trasmitido en sus libros todo el saber del Oriente, pues absorbiendo en su lengua todos los dialectos semíticos y parte de otros idiomas, y recogiendo con sed inagotable de saber todas las tradiciones y conocimientos de las naciones y tiempos antiguos, han conservado documentos y noticias de la mayor importancia. La ventajosa posición de la Arabia entre las naciones más ilustradas de Oriente y Occidente, entre el Egipto, la Judea, la Siria, el imperio griego, la Persia y la India, fue mucha parte para que los árabes, tratando ya en sus puertos, ya en los mercados extranjeros con viajeros y naturales de todas aquellas comarcas, se instruyesen en sus ciencias, historias y demás conocimientos, como ya lo hemos indicado, y en otro lugar se dirá más detenidamente. Aunque crédulos y exagerados con frecuencia, reúnen los árabes dos cualidades de gran utilidad para la ilustración de la historia. Una de ellas es el espíritu conservador con que siempre han procurado guardar inalterables las tradiciones, costumbres y monumentos antiguos, y así es como en la Siria y en la Arabia conservan aquellas gentes los antiquísimos linajes y nombres de las ciudades y tribus designadas por los autores hebreos y los antiguos griegos. Todavía se encuentran en sus 
cabilas y poblaciones los nombres antiquísimos de los Homeritas, hoy Himyaritas, de los Hadramitas, hoy los de Hadramaut, de los Safaritas, hoy los Benu-Tdafar ó Zafar, de Edén o Adane hoy Aden; de Haran hoy Harran de Negrana, hoy Nageran, de Ailat hoy Aila de Mariaba, hoy Mareb; de los Mineos, Omanitas y Maranitas, hoy las gentes de Mina, Oman y Mahra. Otra cualidad que realza mucho la importancia de los árabes, como historiadores, es su tolerancia e imparcialidad en respetar los usos, leyes y creencias de otras naciones sin que el fanatismo religioso les moviera a adulterar la verdad en sus relatos. Si en los tiempos antiguos fue su Caba de la Meca un panteón en que se adoraban las divinidades de muchos pueblos, después que abrazaron el islamismo no dejaron de mirar con el mismo respeto religioso los lugares sagrados para israelitas y cristianos, gloriándose que la Caba fué fundada por Abraham, conservando el nombre y la memoria de la roca de Moisés, sepulcro de Aaron, y monte Sinaí, llamando á Jerusalem Medina al Cods ó ciudad santa; y no mencionando jamás á Isa Ebn Meriem ó Jesucristo, a sus apóstoles y a los antiguos profetas, sin acompañar a sus nombres una fórmula de reverencia y respeto. Así en España el terrible Almanzor se abstuvo de profanar el sepulcro de Santiago; los conquistadores árabes dejaron a nuestros cristianos en el libre ejercicio de su religión, y hasta un jurisconsulto cordobés llamado Chafar Rawadi, declara terminantemente que los cristianos sujetos al imperio muslímico, pueden poseer bienes de fortuna y tener templos para sus cultos religiosos. Con estas observaciones, al par que se colige lo útil que es el espíritu conservador y tolerante de los árabes para la exactitud é imparcialidad histórica, se puede corregir la exagerada idea que por muchos se ha tenido del fanatismo musulmán.

En el ramo de la numismática, que es uno de los mayores auxiliares de la historia, es útil el árabe para descifrar, no solo las numerosas monedas y medallas acuñadas por estas gentes en Oriente y Occidente, sino también muchas batidas con inscripciones árabes en la India, Persia, Circasia, Turquía, etc., con caracteres árabes y griegos en el imperio oriental; con árabes y latinos en España y en África por los valles de los primeros califas, y después en diversos países por varios reyes y señores cristianos, como los reyes de Sicilia, el conde de Tolosa y obispo de Magalona y nuestro rey D. Alfonso VIII, todas las cuales son muy útiles para esclarecer las relaciones de sarracenos y cristianos durante los siglos medios.

La larga e incorrupta antigüedad del idioma árabe ofrece asimismo gran importancia para ilustrar la lengua y antigüedades sagradas de los hebreos, porque en los libros del viejo testamento hay multitud de voces que no tienen sus raíces sino en el árabe; porque algunos de ellos, en particular el de Job, no puede comprenderse bien sino conociendo a fondo la gramática, literatura y costumbres de los hijos de Ismael, porque el Targum, antigua versión caldea del Pentateuco abunda en arabismos, y por otras mil razones fundadas en la comunidad de origen, de tradiciones y aun de gusto literario. También para la literatura profana de los hebreos es importante el conocimiento de la arábiga; pues aquel pueblo, viviendo en medio de los árabes, ha hablado y escrito como ellos, y en el árabe se hallan admirables versos del famoso judío Samuel Ebn Adia.

"Este idioma, dice un ilustre arabista $\left({ }^{20}\right)$, es la lengua madre de los pueblos que habitan las tres Arabias, la Siria, la Mesopotamia, la antigua Caldea, el Egipto, la Nubla, el Sahara, el Biledulgerid, los reinos de Fez, Túnez, Marruecos, Trípoli y Barca. Con ella se puede viajar por Turquía, por la Anatolia, la Armenia, la Persia, la India y la Tartaria; por la Habisinia, por las costas de Zanguebar y las del Senegal. El árabe se habla o se comprende en todos los países donde ha penetrado el islamismo, porque el Corán se enseña a los niños en su texto original, y se lee todas las semanas en las mezquitas, y así el árabe es sumamente útil a los viajeros que van a buscar en el Oriente instrucción, recreo o fortuna".

\footnotetext{
${ }^{20}$ Juan Humbert antes citado.
} 
Pero el estudio del árabe es utilísimo, sobre todo por los tesoros literarios que encierra este idioma, pues sin su conocimiento no es posible leer y aprovecharlos muchos libros de todas las ciencias y artes escritos por aquellas gentes, y de los cuales pocos son todavía los traducidos. Sabido es que ellos inventaron el álgebra, adelantaron la trigonometría, enseñaron a los occidentales las cifras numerales y aritmética india; perfeccionaron con nuevos estudios y descubrimientos las noticias que ya tenían en astronomía, en parte suyas y en parte aprendidas de otras naciones, fueron los primeros en aplicar la química a la medicina; en esta, en la botánica y otras ciencias naturales, adelantaron sobre manera, dieron impulso a la filosofía y salvaron del naufragio muchos escritos de Platón, Aristóteles, Arquímedes, Clemente Alejandrino y otros maestros en aquellas ciencias. Perdidos, por el estrago de los tiempos, los originales de muchos de estos autores, se han conservado en las traducciones arábigas, como se echa de ver en la tabla de Cébes, cuya traducción árabe es más completa que el texto griego que hoy se conserva. Además, los antiguos árabes ilustraron las historias de los Persas, Indios, Hebreos y otros pueblos; y los modernos las de los egipcios, abisinios y otros africanos, y muchos puntos de las historias cristianas como de las Cruzadas, de la iglesia de Egipto y otras de Oriente. En geografía se les deben importantes y exactas descripciones de los pueblos orientales y occidentales, y ellos en fin, han escrito numerosos tratados sobre gramática, retórica y poética, compilaciones literarias y diccionarios enciclopédicos, biográficos é históricos, sin contar sus libros místicos y religiosos. Las historias de los mismos árabes ofrecen grande interés para las demás naciones; pues abrazan en animada, relación hartas grandezas, triunfos, hechos ilustres que imitar, alzamientos y caídas maravillosas de imperios, revoluciones políticas y religiosas, y largas páginas en fin de glorias militares, artísticas y literarias. La historia de los árabes es la del mundo en un gran período, en que ellos solos brillan, y en ellos se refunden todo el saber y la ilustración de los humanos. Por último, señores, la dominación de los mahometanos en muchos países de Oriente y Occidente, la historia de las Cruzadas, las bellezas, maravillas y doctrinas del Oriente, las expediciones y conquistas de los franceses en Siria, Egipto y Argel, el libro de las Mil y una noches, los viajes de Ali Bey, Burckart, Volney, Chateaubriand y Lamartine, y otras mil razones recomiendan a las naciones civilizadas del occidente el estudio de la lengua y los monumentos árabes. Pero en lo tocante a nosotros los españoles, son tantos los motivos especiales de interés y necesidad que llaman nuestra atención hacia tales estudios, que fuerza es entrar más detenidamente en su examen y consideración.

FRANCISCO JAVIER SIMONET.

DISCURSOS sobre la importancia de los estudios árabes, pronunciados en el Ateneo científico y literario de Madrid (II)

\author{
La América, 24 de diciembre de 1858 \\ POR DON FRANCISCO JAVIER SIMONET.
}

Señores, demostrada en la lección anterior la utilidad que los estudios árabes presentan en general para la Europa sabia, la cual de todas las literaturas recoje ansiosa elementos de ilustración, permítaseme examinar más detenidamente la importancia y aun necesidad de tales conocimientos para nosotros los españoles.

Si empezamos por la parte geográfica y monumental, aunque van trascurridos cuatro siglos desde la completa restauración de España, todavía se conservan en ella recuerdos y vestigios indelebles de aquellos conquistadores. Aun en nuestro suelo, como en las comarcas de Arabia, Siria, Egipto y Berbería, habitadas por los árabes, se ven poblaciones con los nombres de Medinas, Almodovares, Albalades, Aldeires y Almonziles $\left({ }^{21}\right)$, pueblos pequeños con el de Almudaínas,

\footnotetext{
${ }^{21}$ Sin duda Almonacid es corrupción de Almonazil ó las posadas.
} 
aldeas y alquerías, palacios con el de alcázares y alcoceres, castillos y fortalezas con el de alcalás, alcoleas y alcazabas, y puentes con el de alcántaras, ríos con el de Guadix y Henares; canales de riego con el de acequias, baños y aguas termales con el de Alhamas, lagos con el de albuheras, estanques y depósitos de aguas con el de albercas y algibes, islas con el de algeciras, rocas con el de Zahara $\left({ }^{22}\right)$, montes con el de gebal, arenales con el de Ramblas, caminos con el de arrecifes, torres y vigías con el de rabitas, atalayas y almenaras. En Córdoba y Valencia hay sitios de recreo, llamados Rusafas, como cerca de Bagdad y en Egipto; en estas como en aquellas regiones hay Guadalabiad y Guadalahmar ó ríos blanco y rojo $\left({ }^{23}\right)$, y pueblos llamados Almansoras, Albaidas y Alhambras, es decir, la vencedora, la blanca, la rubia, Farajanes $\left({ }^{24}\right)$ ó deleitosos, y lugares fundados por tribus arábigas, cuyos nombres empiezan por Beni, los hijos ó familias. Y no solamente en Andalucía, Valencia y Murcia, sino en todo el Aragón, en ambas Castillas, en Extremadura y en Portugal, abundan los pueblos de fundación y nombre árabe. No nos detendremos en estas curiosidades, por llamar nuestra atención otras de más importancia. Solo recordaremos que hasta en las provincias más septentrionales hay poblaciones con nombres arábigos, y en los demás son innumerables. En Andalucía, Murcia, Valencia y las islas Baleares, abundan pueblos que con el antenombre de Beni, o hijos de tal, guardan el de las tribus árabes que allí vinieron a establecerse, como Bena Mahoma, Benadalid, Benagalbon, Benahabis, Benicalaf, Beniza, Benímelich, Benaudalla, Beniganem, Benimuzlem, Benizembla, y otras sin número. Lo propio debe notarse en cuanto al vecino reino de Portugal, pues allí hay Almeida, ó la ciudad de la mesa, famosa en las historias árabes, Albalades, Albuferas, Alcázares, Almodovares, Cadimas, río de Almanzor, etc.

En estos pueblos de nombres árabes, los edificios, las costumbres, muchas voces del lenguaje vulgar y hasta la fisonomía de los moradores, conservan huellas y rasgos de aquellas gentes. Aun se ven en Granada, Sevilla y Córdoba suntuosas mezquitas, convertidas en templos con selvas de columnas, magníficos y aéreos alcázares con la misma arquitectura que se admira en Marruecos, Egipto y Siria. El alcázar de Sevilla, la catedral de Córdoba, la Alhambra y Generalife $\left({ }^{25}\right)$ de Granada, la Aljafería de Zaragoza, y otros monumentos de nuestra España, cuentan, ya que no rivales, otros semejantes en las costas y ciudades musulmanas de África y el Oriente, pregonando estos como aquellos las glorias del pueblo árabe en tan apartados confines del mundo. Y todavía en Sevilla, Granada, Úbeda, Baeza y otras ciudades moriscas hay aposentos sombríos en medio de jardines y con fuentes debajo de altas bóvedas a la usanza de Sanaa, el Cahiro, Damasco y otras poblaciones orientales. En estas poéticas mansiones y bajo aquellos fantásticos alcázares, se ven discurrir moradores de sangre árabe, revelándolo en el fuego de sus ojos, en lo tostado de la tez y en los rasgos de la fisonomía; y a veces hasta en el traje, pues mucho semeja al de los moros el ordinario de la gente del pueblo en el reino de Valencia, y los mantos y embozos de las mujeres en Tarifa. Particularmente en Andalucía, país que más he recorrido, he visto aquellas mujeres de quienes cantó nuestro gran poeta Zorrilla:

“Moran allí esas célicas huríes

que pintan las muslímicas leyendas,

reclinadas en frescos alhamíes,

sobre lechos de azahar, bajo albas tiendas

cuya generación guardarán solas

\footnotetext{
${ }^{22}$ Zahara de la provincia de Cádiz, está sobre una roca.

${ }^{23}$ El Guadalaviar y el Guadalimar.

${ }^{24}$ En Andalucía y en Berbería.

${ }^{25}$ Debe escribirse Genalarife, vergel del arquitecto.
} 
las árabes provincias españolas."

Y no solo la estirpe y linaje árabe se conserva aun en muchos naturales de aquellas provincias, sino que hasta sus apellidos son de aquella lengua, como Medina, Alcázar, Tarafa, y Tarfe, Venegas, Adalid, Galvez, y otros sin número que pudiera citar.

También se ven a cada paso por aquellas provincias el corcel negro, impetuoso y volador de raza árabe y el jinete ágil, diestro y bizarro, tipos tan característicos de los hijos del desierto. Hasta la misma naturaleza, para que sea más completa la ilusión, ha adoptado las plantas y árboles traídos aquí por aquellas gentes, como la palma, que ya solitaria, ya formando bosquecillos, descuella en Andalucía y en los reinos de Valencia y Murcia, el granado, el jazmín y bosques de naranjos, limoneros y olivos, palmitos, pitas y aloes, como en África y Asia. Sabido es que entre las plantas, árboles y flores, la azucena, el almoradux, el alhelí, el azafrán, la albahaca, la anémona, el azahar, el arrayan, el jazmín, el naranjo, el albaricoque, el alerce y otros mil llevan nombres árabes, y sin duda fueron importados por aquellos conquistadores.

A estos nombres de geografía y agricultura hay que añadir otros innumerables del mismo origen que han quedado en el lenguaje vivo y usual de nuestros españoles, señaladamente en las provincias de Oriente y Andalucía. Como de este asunto trataré ex-profeso en otra lección, solo diré que son árabes la voces alfombra, almohada, zaragüelles, alcalde, azotea, albañil, alarife, noria, laúd, alcoba, guzla, adarga, y otras sin cuento. Asimismo embellecen nuestro idioma actual muchas frases y giros adoptados del árabe, sobre todo, en Andalucía y Valencia: de ellos hemos tomado nuestro articulo él, y hasta una letra y pronunciación gutural, la jota, nos ha venido del mismo origen $\left({ }^{26}\right)$. El estilo figurado, florido y ameno, las metáforas y exageraciones que se notan en la conversación de los andaluces ¿qué son sino reminiscencias del árabe? Gran parte de la pompa y sonoridad de nuestro idioma castellano, se la debemos a la influencia y elementos que recibió del árabe, y todavía la imitación de esta lengua puede suministrar a la nuestra muchos giros, rasgos y expresiones felices y rica copia de imágenes para nuestra poesía, como antes la prestó a nuestros romanceros, y todavía a algunos de nuestros modernos vates, como á Arolas y Zorrilla. En los versos de este gran poeta, sobre todo, en su poema de Granada, se encuentran muchas imágenes y locuciones felizmente imitadas del árabe, y aquellos versos:

"Mar azul cuyo lomo cristalino

A las quillas de Agar prestó camino."

No pueden menos de recordarnos la frase árabe rácaba albahr, cabalgó el mar, con que esta gente en su poética lengua expresa el pasar el mar, como si este tuviera lomos é hijares dóciles a las espuelas de los remos.

Tantos y tales son, señores, los vestigios y recuerdos de aquella nación en España, que bien podemos afirmar que sin el estudio del árabe no es posible comprender nuestro pasado ni aun descifrar nuestros problemas y arcanos en aquello mismo que nos rodea. Vivir entre los monumentos de otras edades sin comprenderlos, es tener ojos y no ver; es no alcanzar nada mas allá del horizonte del presente, siempre limitado y escaso para la vasta inteligencia del hombre. Pero con la luz de los autores árabes descifraremos hartos enigmas escritos en la piedra y en estuco de preciosos monumentos, admirando en ellos las artes y el ingenio de un pueblo eminentemente civilizador. En los bosques de columnas de las mezquitas y alcázares reconoceremos el genio arquitectónico inspirado por los bosques de palmeras y pintorescos paisajes de oriente. En las elegantes inscripciones que los adornan leeremos, ora preceptos de su religión, ora alabanzas a Allah, ya recuerdos históricos, ya testimonio de sus glorias, y ya también

\footnotetext{
${ }^{26}$ Lo mismo debe decirse de la aspiración fuerte que dan los andaluces a la $\mathrm{h}$ en muchas voces, pronunciando jerpil por herpil, jorno por horno, jacha por hacha, jarambel por harambel.
} 
de las nuestras. Si en el alcázar y la mezquita de Córdoba leemos los loores de los califas Abderrahmanes y Abdallahes y de las obras que ejecutaron para la gloria de Allah y del islamismo; si en los monumentos de los Naseritas en Granada y Málaga leemos la religiosa y modesta divisa La Ghaleb Illa Allah, solo Dios es vencedor, para confusión del orgullo de otros conquistadores, en el alcázar de Sevilla edificado por arquitectos árabes después de la reconquista se lee: "La gloria para nuestro señor D. Pedro a quien Allah ayude y proteja." Porque los árabes, señores, no quisieron que sus paredes fuesen mudas, sino que hablando al alma mientras recreaban los ojos, les sirviesen de útil libro siempre abierto y pródigo en la enseñanza, pareciéndoles insuficiente el mudo y material adorno de follajes y labores. También con la misma luz descifraremos en Granada y otras partes las leyendas de sus reales sepulcros, que juntamente con el nombre y elogio de sus inanimados moradores encierran magníficas elegías, que por la belleza de los versos y las imágenes derraman luz y alegría en las mismas sombras de la muerte. Y no es exageración, pues conocido es el genio poético de los árabes, que a sus cementerios los llaman con el risueño nombre de raudha o vergel. -También una inscripción árabe grabada en el sepulcro de San Fernando en Sevilla, con otras latina y hebrea, testifica la gloria de este gran monarca español que tuvo súbditos árabes, judíos y cristianos.

Igualmente notoria es la utilidad del árabe para interpretar muchos pergaminos escritos en este idioma, jarrones, banderas, armas, monedas, ya árabes ya bilingües y otras antiguallas que cada día se descubren y que descifra el estudioso de aquella lengua para luz de nuestra historia. Y a propósito de las monedas, ofrecen gran curiosidad para los mismos cristianos de España, y son gloriosas para nosotros las acuñadas en Toledo por el rey Alfonso VIII de Castilla para uso de los infieles subyugados, y cuya inscripción árabe lleva el nombre del Papa romano Imam o gefe de la Iglesia cristiana, la profesión de nuestra fé y dogma de la Trinidad y el nombre de Alfonso con el título de Emir de los católicos a quien Allah ayude y favorezca.

Y si pasamos a examinar la utilidad del árabe para ilustrar nuestra historia y geografía de los siglos medios; icómo las tinieblas de esta edad se desvanecen y se allanan sus dificultades hasta ahora invencibles, con el estudio y consulta de aquellos autores! Inmenso como desconocido y no trillado es el campo que se despliega ante nuestros ojos. Sí examinamos las crónicas y documentos de aquellos siglos, en su mayor parte los hallaremos sembrados de arabismos, como alfatenas $\left({ }^{27}\right)$ arrehenes, trujamanes $\left({ }^{28}\right)$, alfaqueques $\left({ }^{29}\right)$, aseifas, alyaras, almaxaneques $\left({ }^{30}\right)$ azor $\left({ }^{31}\right)$, zuna $\left({ }^{32}\right)$, alfoz $\left({ }^{33}\right), y$ otros mil, cuya verdadera significación no es posible comprender sin mucho conocimiento de esta lengua. De otra suerte nos expondremos á incurrir en los ridículos extravíos en que tropezaron ciertos autores castellanos por esta ignorancia, como el que tomó por nombre de un capitán moro la palabra aseifa, que significa hueste y expedición de verano. Sin la lectura de los historiadores árabes, era imposible comprender, por ejemplo, que el Carsabodenes de nuestras crónicas $\left({ }^{34}\right)$ es Alcázar de Sal a quien aquellos autores llaman alcázar de Ebn Abi Danés; que el ir á Alaxarch, que parece ir a algún pueblo de este nombre, quiere decir ir al oriente de España, pues Axarq, en árabe, es oriente. Es cierto que por lo menos hasta fines del siglo XII

\footnotetext{
${ }^{27}$ Guerra, discordia.

${ }^{28}$ Intérpretes.

${ }^{29}$ Redentores de cautivos.

${ }^{30}$ Ingenio, máquina de expugnación. // // (10) Véase el citado Bayan. (11) Véase el autor árabe del CartUas. ed. de Leiden y otros.

${ }^{31}$ Muro.

${ }^{32}$ Ley mahometana.

${ }^{33}$ Término, jurisdicción.

${ }^{34}$ Anales toledanos.
} 
nuestros cristianos escribían en una lengua, o por mejor decir, jerga bárbara, mezcla heterogénea y discorde del latín, el árabe y otros dialectos que iban dando lugar a la castellana.

Pero la mayor importancia de los escritores árabes es para suplir la escasez, oscuridad é ignorancia que se nota en la mayor parte de nuestros documentos históricos de aquellos siglos, a veces para confirmar los hechos dudosos que en ellos se contienen, y apurar la verdad de muchas noticias atribuidas a los árabes, y en fin para buscar las verdaderas fuentes de nuestras historias y servir de comprobantes a los testimonios de nuestros cronistas. En cuanto a lo primero, solo por los autores árabes se puede tejer un relato continuado de los sucesos de aquellos siglos: en ellos se encuentran curiosísimos datos sobre las guerras, alianzas, mutuos auxilios, tratados y relaciones que la vecindad ocasionaba entre moros y cristianos. Por ellos se ha puesto fuera de toda duda la existencia del gran héroe de nuestra historia, el Cid Campeador, controvertida sin razón por críticos escépticos. Y no solo se reivindica la autoridad de varios documentos cristianos que testifican las proezas de aquel gran caudillo, y que también se habían puesto en tela de juicio por aquellos incrédulos razonadores, sino que, además, se halla luz para trazar otro relato de aquel guerrero, más fiel y menos apasionado que el conocido hasta ahora. En los historiadores árabes se ve asimismo descrito con vivos colores el humilde principio de la monarquía de Asturias y de nuestra restauración, emprendido por pocos cristianos que, retraídos en aspereza y sustentándose de miel y raíces silvestres, no inspiraron recelo alguno aquellos conquistadores $\left({ }^{35}\right)$. Por ellos se tienen noticias más exactas e íntimas de la existencia de aquel pueblo cristiano, mozárabe enclavado entre los musulmanes de Toledo, de Córdoba, Málaga y otras poblaciones del Mediodía, y casi sin comunicación con sus hermanos, ya libres y restaurados de allende las fronteras: se saben las formas de su gobierno civil y espiritual, los lugares en que moraban sus templos, prácticas y ritos religiosos, y demás circunstancias de su propia condición que conservaban entre los moros, así como también los usos que de ellos fueron tomando, y se descubren muchos nombres, de prelados, cadhies y otros personages de aquellos cristianos que no constan en los documentos latinos que de ellos se conservan. Se ve que, entre ellos, a imitación de la Córdoba sarracena, había un centro de civilización cristiana a donde, en tiempos bonancibles, acudían a aprender los cristianos ya restaurados de España y allende los Pirineos. Se les ve a veces levantarse con el calor de algún caudillo de su propia raza y causar una revolución temible, como la que sostuvieron durante largos años el famoso Ornar Ebn Hafsun y sus hijos en la provincia de Málaga y sus confinantes $\left({ }^{36}\right)$. Se les halla a veces usando de trajes y nombres moros, y empezar a formar, sin embargo, en medio de sus opresores, un idioma, hijo del latín, muy semejante a nuestro castellano, como se ve en muchas palabras que conservan los mismos historiadores. Mencionan estos en la provincia de Málaga el castillo Bonít ó bonito, Wadi binnas, rio de las viñas, y el castillo de Dos Amantes; cerca de Córdoba Theliares ó tejares; cerca de Sevilla Billa nuba ó Villanueva; y, lo que es lo mas extraño, una plaza fuerte empezada a edificar en el siglo X por los árabes; pero tal vez por mano de aquellos cristianos, con el nombre semi-latino de Castro Dzacuan, hoy Coin.

Por los árabes sabemos también que el templo de Santiago de Compostela y el de Iria Flavia, ilustrados ambos por el sepulcro de aquel apóstol, eran visitados en los siglos medios por peregrinos, no solo del continente europeo, sino del Egipto y de la Nubia, y se halla confirmada la tradición del maravilloso arribo del cuerpo de Santiago a aquellas costas. Los mismos historiadores, al contar la famosa entrada y devastación de Galicia por Almanzor, nos dan sobre aquel suceso curiosísimos pormenores, que los nuestros pasaron en completo olvido, entre ellos noticia de varios pueblos y sitios notables por donde llevó su itinerario aquel gran caudillo. En los

\footnotetext{
${ }^{35}$ Autor árabe del Bayan Almoghreb, ed. de Leiden y otros.

${ }^{36}$ Véase el citado Bayan.
} 
historiadores árabes encontramos largas relaciones de sucesos importantísimos, contados en dos palabras por nuestros rudos y concisos cronistas, como de la desastrosa jornada de Zallaca, en que fue derrotado el rey de Castilla D. Alfonso el VI. Á veces por ellos se ven comprobados hechos muy gloriosos para los nuestros, y que por la misma grandeza del suceso y la fortuna creíamos exageraciones y patrañas de nuestros cronistas, como la matanza increíble de las Navas de Tolosa, cuya pérdida calculan los mismos árabes en cerca de cuatrocientos mil hombres $\left({ }^{37}\right)$, y dos siglos y medio antes la gran derrota de Abderrahman III en la hoya de Zamora $\left({ }^{38}\right)$.

Sería larguísimo el apuntar las noticias curiosas e importantes con que los árabes esclarecen nuestras historias de aquellos tiempos. En cuanto a las relaciones, auxilios y alianzas entre moros y cristianos, los autores árabes demuestran, como los castellanos y leoneses, ya por desabrimientos con sus soberanos, ya por buscar palenque en donde satisfacer con el duelo sus rencores y agravios, ya por la esperanza de la recompensa, o ya por fomentar las disensiones intestinas de los mahometanos o por procurarse su alianza en sus propias revueltas, pasaban a Córdoba y se alistaban en las huestes musulmanas. A veces, para confusión y desdoro de los malos cristianos, muestran a muchos de sus condes y señores que, instigados del temor o la codicia, prestaron sus servicios a Almanzor y otros caudillos moros. A veces, para gloria nuestra nos refieren, por ejemplo, como el ínclito rey San Fernando envió en socorro del Emir Almohade Almamun, un cuerpo escogido de doce mil caballeros cristianos, obteniendo en cambio, además de muchos castillos y fortalezas, el que se erigiesen en la ciudad de Marruecos templos para el culto cristiano, en donde aquellos auxiliares y los mismos infieles que quisiesen convertirse a nuestra religión, pudiesen acudir a profesarla libremente y al son de campanas; hecho importantísimo de que nuestras crónicas no dan la menor noticia. Con el estudio de los autores árabes se corrigen muchos errores históricos, entre ellos el que cometió el doctísimo P. Mariana, haciendo dos personas diferentes de Ebn Tumert, llamado Almahdi, que fundó el imperio y dinastía de los Almohades. En ellos se encuentra asimismo la fuente de muchos historiadores cristianos; pues en la crónica general, en la leonesa, en la del arzobispo D. Rodrigo, en la de Alfonso el XI, se hallan largos pasages tomados de autores árabes que hoy se encuentran en los textos originales de estos historiadores. El estudio del árabe es indispensable asímismo para interpretar muchos albarás, conciertos de paces, privilegios y otros documentos otorgados por los mismos moros en favor de los cristianos, como el concedido por el Emir almohade Yusuf Almuntassir Billah á los monjes de Poblet $\left({ }^{39} 2\right)$, y sobre el cual, por no haberle sabido traducir algunos escritores, habían inventado ridículas consejas. El cotejo en fin de los escritores árabes con los cristianos, es utilísimo como decisivo en los hechos dudosos que ofrece nuestra historia de aquellos siglos; pues ello es indudable que cuando unos y otros se ponen de acuerdo sobre algún suceso, se reunirán en él todas las razones de prueba y autoridad que puede exigir el criterio histórico.

De todo esto se colige la necesidad de los estudios árabes para ilustrar y aun rehacer una parte muy considerable de nuestra historia. Aun en la parte que atañe únicamente a nuestros muslimes, es importantísima su historia, pues nos presenta glorias y altos hechos que recaen en loor de nuestra España, cuyos moradores fueron durante tantos siglos, capitanes y guerreros famosos, sabios y poetas ilustres, monarcas y conquistadores que dilataron sus señoríos por España y África, otros espléndidos y magníficos en adornar nuestro suelo con ricos monumentos de las artes y en proteger las letras, y todos ellos respetados y obsequiados con presentes y homenajes de

\footnotetext{
${ }^{37}$ Véase el autor árabe del Carthas.

${ }^{38}$ De Aljandic la llaman los árabes.

${ }^{39}$ Documento publicado traducido por el Sr. D. Pascual Gayangos en el Memorial Histórico.
}

REIM № 29 (diciembre 2020) ISSN: $1887-4460$ 
soberanos y príncipes de Oriente y Occidente : tales son los lauros y blasones de los árabes que dominaron en nuestra Península.

En lo tocante a la geografía, gran auxiliar de la historia, los autores árabes nos han conservado los nombres de muchos pueblos romanos, o anteriores al menos a su conquista, que, adulterados después, dejan hasta duda de donde estuvieron situados. Ellos nos hacen ver en la isla de Salthix, hoy Saltés, la antigua Tharsis ó Thartesis; en Bolcuna, hoy Porcuna la antigua Chulco; en Ilia, hoy el Padrón; la antigua Iria Flavia, en Mentixa, hoy la Guardia del reino de Jaén, la antigua Mentesa. Ellos nos ponen fuera de toda duda, que la actual Huelva fué la antigua Onuba; pues sus autores más antiguos escriben el nombre de este pueblo Unoba; y que la antigua Ossonoba estuvo cerca de donde hoy Faro en Portugal; pues escriben Santa María de Ocsunoba $\left({ }^{40}\right)$, y sabido es que Faro se halla cerca del cabo de Sta. María. Merced a ellos, se ve casi con certeza contra la opinión hasta ahora recibida, que el antiguo Lobetum no fue Albarracín, que tomó su nombre de un Emir moro llamado Ebn Razin, sino Aledo en Murcia, castillo famoso en los siglos medios, que los árabes escribieron Albith, y luego Alith; y que Medinaceli no viene de Methimna, sino de Medina, en su lengua ciudad, y de el nombre de un moro llamado Selim.

Por los mismos autores venimos en conocimiento de que no eran romanas las ruinas de Córdoba la Vieja sino árabes del famoso alcázar de Medina Azzahrá, viniendo el error de que los moros imitaron en aquellos palacios la arquitectura bizantina, como lo confiesan sus historiadores y de que muchas columnas y piezas de mármoles de los que se emplearon en su construcción, fueron traídos de las ruinas romanas de Cartago, según lo hemos leído en un autor árabe. Ellos borraban menos que nosotros los antiguos vestigios, porque según hemos observado en otro lugar, los árabes eran sobremanera conservadores, y así es que ellos escribían Sant Yacub, antes Sanctus Jacobus, Ixbilia antes Hispalis, Nebrixa antes Nebrissa, Ujxama antes Uxama, Libla antes Ilipla, Colunia antes Clunia, nombres que hoy cuesta trabajo reconocer o al menos se hallan muy desfigurados en Santiago, Sevilla, Lebrija, Osma, Niebla y Coruña. Ellos nos conservaron igualmente el nombre y los recuerdos de muchas antiguas poblaciones, que después han desaparecido como Secunda, población antigua y murada junto a Córdoba, Liwaria antes Nivaria, hoy desaparecida, Tálica antes Itálica, Aurith antes Oretum, Elbira antes Iliberis. También nos presentan multitud de nombres geográficos, ora árabes, ora latinos o de otras lenguas, cuya correspondencia con los actuales o sus vestigios pueden fijarse por sus noticias, y los de algunos que mencionan nuestras crónicas, pero que ya han cambiado como Poley, en árabe Bolay, hoy Aguilar cerca de Cabra. Los árabes, por último, nos han dejado en sus libros muchas, exactas y elegantes descripciones de los pueblos de España por donde se echan de ver su antigüedad, su importancia, sus artes, agricultura y comercio. Entre ellas son curiosas las de Zamora y sus fortificaciones, las de Córdoba, Almería, Málaga, Ronda, Granada y otras muchas que omitimos por no dilatar demasiado este discurso $\left({ }^{41}\right)$.

En los árabes encontraremos asimismo el origen de muchas instituciones, usos y descubrimientos, que han alcanzado después gran importancia en nuestra España y en otras partes de Europa. En este punto, debemos hacer particular mención del espíritu caballeresco, el homenaje de admiración, rendimiento y galantería tributado al sexo hermoso y débil; las aventuras, torneos, duelos y lances de honor emprendidos en su obsequio, costumbre interesante, que tan en boga empezó a estar declinando la edad media. Todo esto nació entre los antiguos árabes del desierto, como se ve por la Sira de Antara, gran epopeya de aquel pueblo, por el libro de los tiernos

\footnotetext{
${ }^{40}$ De Ocsunoba ú Ossonoba se hallan algunas curiosas noticias en el historiador Almaccari texto árabe ed de Leiden 1855. Llamóse también por los árabes Sta. María de Algarbe o de Occidente, a diferencia de Sta. Maria de Albarracín o de Oriente.

${ }^{41}$ Muchas de ellas se hallan en la mencionada obra de Almaccari.
} 
amantes e historias de los Benu Odzra $\left({ }^{42}\right)$, en donde se enumeran notables extremos y sacrificios de amor hechos por los árabes, y por otros documentos de esta nación. Tal costumbre se remonta a la época de aquel famoso caudillo y poeta Antara o Antar, el padre de los caballeros, el Amadis del Oriente, como le llama un célebre arabista $\left({ }^{43}\right)$, que tantos riesgos, difíciles empresas y persecuciones arrostró por merecer el afecto y la mano de la hermosa Abla. Cuánto interesa, en verdad, el leer como aquel guerrero, al dar el grito de batalla invocaba juntamente el nombre de su patria y el de su amada exclamando: “iOh pueblo de Abs, oh Abla amada mía!” y cuando al volver del combate la dirige estos versos:

"De ti me acuerdo cuando las lanzas vibran entre nosotros

y en tanto que beben nuestra sangre sus crispados aceros."

El germen de los sentimientos caballerescos, según observa un orientalista, se encuentra en los siguientes versos que compuso Antara en memoria de una jornada célebre:

"Nosotros protegimos en Alforne a nuestras mujeres

y apartamos de ellas el fuego de la encendida lid."

"Guardas somos de su honra y nuestro mayor afán es por asegurarles reposo y gloria."

Del poeta Alferazdac $\left({ }^{44}\right)$ y otros se cuentan extraordinarias finezas de amor que ejecutaron por las damas de sus pensamientos. En los certámenes poéticos solía nombrarse por juez y arbitro a alguna dama ilustre, y se cuentan, en fin, largas y sangrientas guerras, emprendidas por aquellos árabes para vengar la afrenta hecha a alguna mujer, como la de Basus $\left({ }^{45}\right)$. Este espíritu caballeresco pasó a España con los árabes, y tomó notable desarrollo bajo el reinado caballeresco de los Nasseritas, de Granada, como se ve por las guerras civiles de Gines Pérez de Hita y los romances castellanos en aquella época. Nuestros árabes andaluces inspiraron a los poetas cristianos españoles y a los trovadores provenzales los mismos sentimientos, y se propagaron por Francia, Italia y otras naciones de Europa.

Las órdenes militares deben contarse también en el número de las importantes instituciones que nos han venido de los árabes. Todavía se conservan en España y en África algunas rábitas, á saber: atalayas y puestos fortificados en las costas y fronteras. Estos eran, los cuarteles de los morabitos, varones piadosos, que dedicados a los ejercicios de la austeridad religiosa, ejercían al propio tiempo la profesión de las armas en la guerra de frontera que es la más recomendada por Mahoma y por los intérpretes de su alcoran. A imitación, pues, de los morabitos, se introdujo entre nuestros cristianos el instituto de hombres ligados juntamente con votos religiosos y con el militar de hacer guerra contra los moros, como lo ejecutaron con gran provecho del Estado y de la cristiandad española. Estos caballeros, situándose en los castillos y plazas fronterizas, trabajaban con incesantes rebatos y alarmas a los morabitos y otros infieles de los castillos inmediatos, y así podemos decir que de los mismos adversarios aprendimos los medios de exterminarlos. Hoy, las órdenes militares, después de propagarse de España en Europa, cesando en su ejercicio, solo se conservan en el nombre y dignidad, mientras los morabitos permanecen en África con la misma vida religiosa y guerrera.

\footnotetext{
${ }^{42}$ La tribu de Odzra es famosa en las historias árabes por la extraordinaria ternura y fineza de pasión con que se amaban los naturales de ella, muriéndose de sentimiento el que se veía obligado a renunciar al objeto de su primero y único amor. El opúsculo a que aludimos se titula: Historia de los Benu Odzra y otros amantes tiernos y forma parte del libro titulado: Suc Alaxwác, por el Bicaí, donde también se contienen la curiosa historia del poeta Chamil hijo de aquella tribu, y otras sobre asuntos de amores. Véanse las mencionadas en la Chrestomathtía Arabica de M. Kosegarten. (Leipsik 1829), pág. 46 y 112, texto árabe.

${ }^{43}$ M. Noel Dervergers en su Arabie. París 1847.

${ }^{44}$ Véase á Noel Desvergers : Arabie, y a Causin de Perceval en Essai sur I'hist. des Arabes avant l'islam.

${ }^{45}$ Véase á los mismos autores.
}

REIM № 29 (diciembre 2020) ISSN: $1887-4460$ 
Semejante a esta institución fue en la edad media la de los almogávares, nombre también arábigo, que significaba los guerreros que ejecutaban algaras y otras incursiones de menor importancia para talar y estragar el país enemigo. Los almogávares, hombres guerreros, feroces y medio árabes, medio cristianos, son famosos en la historia de aquellos tiempos por grandes servicios que prestaron a nuestros reyes, y por la memorable expedición de Oriente, en que se hallaron con los catalanes y aragoneses. El mismo origen moro cuentan los caballeros alfaraces, que tuvieron a su servicio algunos reyes de León, así como también los almocadenes, adalides, alcaides, zavalmedinas y otros cargos militares y civiles que suenan en las historias de aquellos tiempos $\left({ }^{46}\right)$, como lo diremos con mas detención en lugar oportuno.

Entre los muchos recuerdos y usos árabes que han quedado en Andalucía, país que conserva tantos rasgos del carácter y genio de aquellos moradores, debemos contar la afición a narrar cuentos e historias, que por lo maravilloso y exagerado de los hechos que se refieren, nos traen a la memoria las leyendas de las Mil y una noches, y los relatos de los jabires y rawies tan famosos en las historias árabes y tan conocidos hoy día en África y Oriente. Los andaluces, poetas a natura, y dotados como los árabes de corazón ardiente y de brillante y exaltada imaginación, dan a estos cuentos el mismo animado, espléndido y fantástico colorido que sus progenitores los árabes. También nuestras veladas y verbenas nocturnas, vienen de las zambras de los moros, que datan nada menos que de la costumbre que tenían los antiguos árabes del desierto de salir de noche a las puertas de sus tiendas para conversar y solazarse a la luz de la luna $\left({ }^{47}\right)$. La más popular de todas las veladas, la de San Juan Bautista, con sus festejos a media noche y sus sortilegios casi supersticiosos, revela sobre todas su origen árabe; pues los moros españoles celebraban mucho esta solemnidad. Yo, señores, que me honro de ser hijo de Andalucía, he fijado mil veces mi atención en el gusto y aspecto árabe de estas y otras diversiones, y he visto a mis paisanos holgarse a la luz del astro nocturno en los cortijos y campos, a semejanza de los antiguos árabes, y entonar al son de la guitarra canciones melancólicas y apasionadas, como las que resonaron en otro tiempo en los vergeles de la Alhambra y Generalife.

Estas observaciones nos conducen a recordar un vestigio muy notable que ha quedado de los árabes en nuestra lengua y literatura. La poesía árabe, ejerciendo la influencia de su superioridad en la poesía castellana y en la provenzal, comunicó a los romanceros y trovadores la animación y estilo apasionado de los orientales, y formó probablemente el romance castellano, el género más popular y característico de nuestra poesía.

Pero sería cuento de nunca concluir el querer probar la importancia de las letras árabes por los vestigios que han impreso en nuestra literatura, civilización y costumbres. Solamente debemos encarecer, como punto que interesa en extremo a nuestra gloria nacional, cuánto nos importa estudiar la lengua y literatura de ese pueblo, que en medio de la rudeza y de la ignorancia de la edad media, brillaba en nuestro suelo con el lustre de sus madrisas o academias llenas de sabios en todas las ciencias y con todo el esplendor y magnificencia de sus artes, con que tan soberbios monumentos erigían en Córdoba, Sevilla y Granada. Entonces además de acudir los estudiosos de muchas naciones á buscar en aquellas madrisas gérmenes y elementos de civilización, sus libros eran traducidos con afán por los judíos, los cristianos españoles y hasta por los italianos y otros extranjeros, a quienes relaciones de comercio o de política unían con nuestros musulmanes. Nuestra biblioteca del Escorial todavía rica, aunque saqueada y quemada muchas veces, las de París, Leiden y otras de Europa, atesoran las obras maestras de poesía, gramática, retórica, filosofía, medicina, matemáticas, astronomía, ciencias naturales, historia, geografía y otros

\footnotetext{
${ }^{46}$ Todavía se conservan entre nosotros los cargos y oficios de alcaldes, alguaciles y otros de nombre e institución árabe.

${ }^{47}$ Esto es lo que significa en árabe el verbo zámara, de donde viene la voz zambra.
} 
monumentos escritos de los árabes de aquellos siglos $\left({ }^{48}\right)$, no menos de oro para las letras que el de Augusto en la antigüedad latina.

¿No es gloria señalada de nuestra España que haya producido botánicos tan excelentes como el malagueño Ebn Aibeithar, filósofos como Abu Roxd o Averroes, médicos y cirujanos como el cordobés Abulcasis Abulcasim, sabios e historiadores como el granadino Ebn Aljathib, poetas como Wallada de Córdoba y Ebn Abdun de Evora, y otros autores ingeniosos y sapientísimos, algunos de los cuales, traducidos después a la lengua latina se estudiaron en las academias de París, Bolonia y otras extranjeras? Continuando nuestras lecciones daremos cuantas noticias podamos de estos autores y libros españoles, y haremos ver la altura a que se elevaron entre ellos todas las ciencias y artes; porque además de su buen ingenio, la ilustración de sus príncipes y monarcas, aquí, como en Oriente, protegió generosamente las letras, alcanzando principalmente esta gloria Alhacam II de Córdoba, Almotassim de Almería, y Almotamid de Sevilla $\left({ }^{49}\right)$.

Es indudable, señores, como lo observa un distinguido orientalista extranjero $\left({ }^{50}\right)$, que de aquella España árabe tan sabia y tan ilustrada, se derramaron por la Europa muchos de los conocimientos que fueron preparando el renacimiento de las letras. Por medio de nuestros árabes, llegaron a los demás europeos preciosos descubrimientos que aparecieron por los siglos XI, XII y XIII y que no llevando el nombre de otros autores, parece razonable atribuir su enseñanza a la única nación que en aquellos siglos fomentaba los trabajos de la inteligencia. El uso del papel, de la brújula y de la pólvora nos ha venido del Oriente, y aunque su primitiva invención parece que debe atribuirse á los indios y a los chinos, sin embargo, a los árabes se debe el haberse iniciado en estos descubrimientos por sus navegaciones y relaciones de comercio con aquellos orientales, y perfeccionándolos, haberlos trasmitido a la España y otras naciones del occidente. Es cierto que este predominio político y literario de los árabes que hemos venido mostrando, terminó hace algunos siglos, y que la civilización muslímica ha sido borrada juntamente con su dominación de estas regiones que tenían usurpadas; pero por las muchas y gloriosas huellas que de ellos han quedado, así en España como en otros países de Oriente y Occidente, se ve que no han sido perdidos aquellos elementos para nuestra civilización moderna. Su actual decadencia nada puede quitar de este lustre y gloria: por ventura porque haya desaparecido nuestra dominación de las Américas ¿rebaja esto la gloria de haber dado a aquellos moradores el idioma, la creencia y la civilización que hoy conservan?

Réstame, señores, manifestar que el fomentar los estudios árabes, es necesario para nosotros, los españoles, si animados de antiguos sentimientos religiosos y nacionales, queremos dar impulso á las misiones de Oriente y restablecer las de África, reivindicando los antiguos derechos que nos asisten para tener templos y casas de misión en el imperio de Marruecos; y más todavía, si con altas y grandes miras pensamos en dilatar algún día por esas comarcas, teatro de nuestras antiguas glorias, la religión del Crucificado y la dominación española.-He dicho.

FRANCISCO JAVIER SIMONET.

\footnotetext{
${ }^{48}$ Como se ve por el catálogo de D. Miguel Casiri Y otros.

${ }^{49}$ Véase sobre el particular á Mr. Dozy en sus Recherches sur I'histoire d'Espagne, tom. I. a Conde y los autores árabes consultados por ellos.

${ }^{50}$ El ya celebrado Mr. Noel Desvergers, Arabie, pag. 4.
} 